Новікова В.Г., стариий науковий співробітник науково-дослідного відділу науково-дослідного иентру воєнної історії НУО України імені Івана Черняховського (м. Київ)

\title{
МІСЦЕ ТА РОЛЬ ЖІНОК У ВОЛОНТЕРСЬКОМУ РУСІ В ПЕРІОД ПРОВЕДЕННЯ АТО (2014-2018)
}

У статті аналізується участь жінок у волонтерському русі, щзо виник у нас під час Революиії Гідності і розгорнувся в ході збройного конфлікту на Сході Украйни. У надзвичайно складний період саме цей рух об'єднав суспільство, створив дієву структуру громадських організащій, груп людей, готових взяти на себе вирімення найбільш нагальних $і$ болючих проблем держави.

Ключові слова: волонтерський рух, жінки-волонтери, антитерористична операція.

У значному розмаїтті волонтерського руху, що виник в Україні у 2014 році, важлива роль належить жінкам, які поряд із представниками чоловічої статі звалили на свої тендітні плечі тягар та відповідальність за забезпечення українських вояків найнеобхіднішим, турботу про сім'ї тих, хто став на захист Вітчизни.

Про жінок-волонтерів 3'явилися перші праці, що оцінюють їх діяльність. Так, у березні 2018 р. у золотій залі Спілки письменників України у Києві презентували першу книгу, видану за підсумками Огляду-конкурсу “Українка: жінка-волонтер, жінка-воїн, жінка-герой” [1]. Героїнями книги стали жінки-волонтери, які дбають про українське воїнство протягом усіх років збройної агресії Росії проти України на Донбасі: збирають благодійні кошти, укладають і доставляють українським захисникам пакунки 3 необхідними речами, медикаментами, військовим спорядженням, домашніми 38 
смаколиками; тримають варту у військових госпіталях; опікуються родинами учасників антитерористичної операції (АТО) та загиблих під час збройної агресії Російської Федерації; створюють новий культурний контент для воїнів Збройних Сил України, відвідують блокпости з концертами тощо. Вони на невидимому фронті наближають нашу перемогу [1].

Журналістський проєкт “Жінка світу” - це збірний образ тисяч українських жінок, які з початку Майдану і до сьогоднішнього дня борються за свободу України. Серед них жінки-військовослужбовці і жінки-волонтери, жінки, чиї чоловіки і сини захищають сьогодні цілісність країни, зокрема Тетяна Ричкова, Дана Ярова, Раїса Шматко та інші. У масштабах країни вплив кожної окремо комусь може здатися малим, але саме вона - “Жінка світу" - сьогодні пише історію нашої країни [2]. Проте проблема участі жінок у волонтерському русі за умов збройної агресії Російської Федерації проти України ще не знайшла належного відображення у науковій літературі.

Мета статті полягає у здійсненні спроби воєнно-історичного опису участі жінок у волонтерському русі у 2014-2018 роках.

Волонтерський рух на повну потужність розгорнувся у 2014 році. На хвилі патріотизму він набув загальнодержавного характеру та отримав підтримку з боку законодавчої i виконавчої гілок влади України. Для забезпечення скоординованих дій волонтерських організацій та Збройних Сил 3 питань забезпечення обороноздатності та мобілізаційної готовності країни, захисту населення у надзвичайних ситуаціях мирного і воєнного стану, контролю за використанням благодійної допомоги та удосконалення системи матерільно-технічного забезпечення при Міністерстві оборони України було створено Раду волонтерів. Це - координаційний орган у питаннях співпраці волонтерських та громадських організацій із Збройними Силами, що безпосередньо виконує функцію громадського контролю за діяльністю та моніторингом виконання програм із реформування Збройних Сил України. У листопаді 2014 року відбулося установче засідання Ради і було обрано її керівний склад. 
До благодійної діяльності та шефської роботи залучалися органи державної влади та місцевого самоврядування, громадські організації та об'єднання, волонтери і окремі громадяни. Шефська робота органів влади над військовими частинами здійснюється відповідно до річних планів. Розмір шефської допомоги Збройним Силам у 2014 р. становив 12,45 млн грн. Із загального обсягу наданої допомоги 69\% коштів становила вартість матеріальних засобів, 17\% - запасних частин та обладнання для ремонту військової техніки та військових споруд, $6 \%$ - фінансування повсякденної діяльності, 5\% - будівельних матеріалів, 3\% - ліків, медичного обладнання та продовольчих товарів, інших робіт.

Крім того, за сприяння органів виконавчої влади i місцевого самоврядування 3 підшефними військовими частинами та загальноосвітніми навчальними закладами було проведено понад 1,8 тис. військовопатріотичних i культурно-виховних заходів та майже 800 заходів із допризовної підготовки.

У рамках акції “Підтримай Українську армію” на рахунки Міністерства оборони України протягом 2014 року надійшло 153,3 млн грн. За рахунок цього фінансового ресурсу було придбано матеріальних засобів на суму 140,9 млн грн (92\%) і медикаментів на суму 12,4 млн грн (8\%). Загальна сума благодійної допомоги, що безпосередньо отримали військові частини протягом 2014 року, становила 426,2 млн грн, у тому числі у натуральній формі - на суму 417,6 млн грн та 8,6 млн грн - у грошовій формі. Таким чином, у 2014 році благодійну допомогу було розширено за рахунок благодійних пожертв фізичних і юридичних осіб та благодійної допомоги в натуральній формі. Загальний обсяг допомоги, отриманої та облікованої Збройними Силами на кінець року, становив майже 580 млн грн [3, с. 48-49].

Станом на 2018 рік волонтерський рух був упорядкований у системі громадських організацій Міністерства оборони України. У 2017-2018 рр. Рада волонтерів спільно 3 волонтерськими організаціями та органами військового управління продовжила діяльність із поліпшення матеріально- 
технічного забезпечення військ (сил) речовим майном, комп'ютерним, спеціалізованим і медичним обладнанням, а також сприяла вирішенню питань психологічної, юридичної та соціальної підтримки військовослужбовців та членів їхніх сімей.

У серпні 2017 р. спільна робоча група з представників Генерального штабу Збройних Сил України та Ради волонтерів здійснили робочу поїздку до районів проведення АТО для оцінювання ситуації щодо соціальноправового забезпечення та проблем, що впливали на стан морально-бойового духу особового складу. За результатами роботи було надано відповідні пропозиції. Моніторингова група щодо аналізу ситуації із відновлення будівництва пунктів постійної дислокації під головуванням Головної інспекції Міністерства оборони України провела інспекцію дев’яти пунктів постійної дислокації бригад у різних регіонах України та районах проведення антитерористичної операції.

Тривала співпраця волонтерських організацій із Адміністрацією Президента України з питань: надання громадянства іноземцям, які брали участь в АТО; виділення спеціального транспорту для евакуації поранених; легалізації транспортних засобів, переданих волонтерами підрозділам Збройних Сил у 2014-2015 рр.; створення дієвого громадського контролю в секторі безпеки і оборони; інформаційного протистояння російській пропаганді та безпеки інформаційного простору; територіальної оборони; соціальних питань та фінансового забезпечення військовослужбовців тощо.

Продовжується надання допомоги 3 питань створення єдиної автоматизованої системи управління військ (сил), системи медичного забезпечення, психологічної допомоги військовослужбовцям та членам їхніх сімей, колишнім військовополоненим, розроблення невідкладних нормативно-правових актів щодо забезпечення життєдіяльності Збройних Сил України [4, с. 99-100].

Науковий аналіз місця та ролі жінок у волонтерському русі, що виник в Україні під час Революції Гідності і розгорнувся під час збройного конфлікту 
на Сході України, неможливий без здійснення воєнно-історичного опису їх участі у волонтерському русі 2014-2018 pр. У цій справі важливим джерелом наукової емпіричної інформації мають стати відомості про діяльність відомих жінок-волонтерів України.

Тетяна Ричкова - волонтер, офіцер ЗС України, помічник Міністра оборони та начальника Генерального штабу ЗС України, народний депутат України. Вона пригадує: "У 2014 році з іншими волонтерами я була неподалік від Донецького аеропорту, коли на мій номер зателефонувала незнайома жінка. 3 коротенької розмови з'ясувалося, що вона пенсіонерка, хворіє, а вся ії пенсія йде на ліки. Вона попросила дати пораду, як їй допомогти війську, сказавши, що має шерстяну пряжу. Я порадила їй в'язати шкарпетки й передавати їх нашим десантникам. Так ось, за кілька місяців ця жіночка зв'язала 150 пар теплих шкарпеток і передала їх волонтерами в одну 3 десантних бригад! Таких прикладів, коли пересічні українці, ледь зводячи кінці з кінцями, допомогли нашій армії в найскрутніші для неї часи, можу навести сотні. Низький їм за це уклін!..”[5].

Iз початком збройного конфлікту на Сході України Т. Ричкова слідом за чоловіком поїхала на фронт для забезпечення українських військовослужбовців у районі проведення АТО. У рідному Дніпрі вона продала деяку нерухомість, приватне підприємство, а також зняла гроші 3 депозитів, щоб купити для 25-ї пдбр найнеобхідніше - форму, берци, генератори. У подальшому Тетяна почала збирати кошти для забезпечення потреб військовослужбовців Високомобільних десантних військ (ВДВ). Вона стала одним із найвідоміших волонтерів, засновницею відділу громадської організації “Крила Фенікса” у місті Дніпро.

Тетяна була на фронті під час найгарячіших боїв у Слов'янську, Краматорську, Червоному Лимані, Ямполі, Дебальцевому, Вуглегірську, Дослідному, Пісках, Авдіївці. Останню машину, на якій жінка вивозила поранених, підірвали прямим влученням міни під Донецьким аеропортом.

У 2014 році чоловік Тетяни загинув під час важких боїв у районі Єнакієвого Донецької області під час обстрілу позицій ворожими "Градами". 
Поховавши чоловіка, вона продовжила займатися забезпеченням військовослужбовців, ставши активним критиком наявного стану речей у Збройних Силах України.

У січні 2015 року волонтерка підписала контракт і стала офіцером 3С України. Була призначена помічником Міністра оборони 3 реформ, 3 весни 2015 року - помічником начальника Генерального штабу ЗС України. Зокрема, Тетяна займалася питаннями дисципліни та психологічного забезпечення в Збройних Силах України, брала участь у розробленні програми психологічної допомоги військовослужбовцям і створенні центрів допомоги учасникам АТО при облдержадміністраціях. Крім того, за її участю створювали Центр розвитку й супроводу матеріального забезпечення Збройних Сил.

У травні 2015 року волонтерку включили до складу Комісії державних нагород і геральдики, а у листопаді - до складу Організаційного комітету 3 підготовки та проведення заходів зі створення Меморіалу українських героїв. Згодом Тетяна очолила державне підприємство, що здійснює матеріальне забезпечення Сил спеціальних операцій та ВДВ.

За допомогу Збройним Силам волонтерка нагороджена орденом княгині Ольги III ступеня (серпень 2014) і орденом Богдана Хмельницького III ступеня (грудень 2014) [6].

Дана Ярова займалася підприємницькою діяльністю, проте стала волонтером під час Євромайдану. Під час бойових дій на Сході України активно провадила волонтерську діяльність у госпіталях і лікарнях міста Києва та області, куди доправляли поранених бійців. 3 часом Д. Ярова налагодила співпрацю 3 американським благодійним фондом і опікувалася реформою медичного забезпечення військовослужбовців у районі проведення АТО. Ярова $\epsilon$ ініціатором, куратором і виконавцем проєкту, в рамках якого, починаючи 3 четвертої хвилі мобілізації, військовослужбовців забезпечували сучасними аптечками 3 кровоспинними засобами. Наразі Дана Ярова "пішла" 3 волонтерства, вважаючи, що завдання забезпечення Збройних Сил держава має виконувати самостійно [7]. 
Волонтер Раїса Шматко справляє враження справжнього солдата: надійного, відважного, який у потрібний момент закриє собою товариша, не побоїться сказати прямо у вічі страшну правду і не втратить сили духу в найнебезпечніших ситуаціях [8]. У “довоєнному” минулому Р. Шматко мала успішну кар'єру чиновника одного з міністерств, працівника банку. Тепер Раїса весь свій час віддає волонтерству, є лідером жіночого руху “За вільну Україну”.

3 травня 2014 року жінка почала двічі на місяць їздити на передову. Спочатку на Луганщину, у 12-й батальйон територіальної оборони, де проходив службу чоловік її подруги, згодом - до тих, із ким разом була на Майдані. Волонтерка регулярно бувала в Пісках, Авдіївці, на шахті Бутівка.

Разом 3 іншими волонтерами Раїса створила у Києві волонтерський центр для збирання допомоги, а також перший в Україні волонтерський логістичний центр у Маріуполі, так званий євросклад, що акумулює гуманітарну допомогу 3 країн Європейського Союзу i дає змогу усім підрозділам, розміщеним у радіусі 50-100 км від нього, отримувати усе необхідне.

Окрім матеріальної допомоги, Р. Шматко дбала і про моральну підтримку учасників АТО та членів їхніх сімей. Зокрема, за їі ініціативи для матерів, які втратили синів під час бойових дій на Сході України, одне 3 кращих у Європі підприємств із виготовлення нагород “Орден” створило спеціальну відзнаку - “Орден матері бійця АТО”. Крім того, за сприяння Раїси для відзначення жінок, які служать військовими медиками, снайперами, психологами, кухарями, а також волонтерами в тилу, було започатковано медаль “Берегиня України”.

Раїса Шматко часто ризикує життям, адже принципово їздить сама в небезпечні місця, має кілька контузій, втратила багатьох товаришів і знайомих. Проте найважчим у волонтерській роботі Раїса вважає не збирання

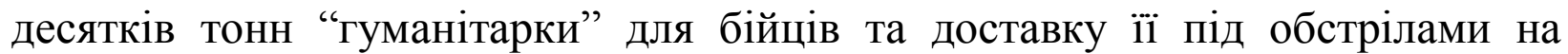
передову, а сумний обов'язок повідомляти матерям про загибель їхніх синів 
[9]. Крім того, на ii думку, існує проблема недооцінення державою волонтерської роботи: ненадання волонтерам статусу учасника бойових дій, недостатня увага до потреб волонтерів з боку місцевої влади, відсутність приміщень для роботи і зберігання гуманітарної допомоги тощо. Утім, незважаючи на негаразди, жінка продовжує благородну волонтерську справу.

3 ініціативи підопічних волонтер нагороджена трьома орденами: “За жертовність і волонтерство”, “Сдність та воля” і орденом Пресвятої Богородиці “Покрова".

Про волонтерку Вікторію Мірошниченко (позивний “Рижик”, батальйон спецпризначення Луганськ-1) кажуть, що вона проривається у найстрашніші місця під час найзапекліших боїв [10]. Вікторія збирає “на базі” тонни волонтерської допомоги, а потім доставляє підрозділам, що найбільше пї потребують, зокрема найнеобхідніше: деталі для авто, ремкомплекти, тепловізори, прилади нічного бачення тощо. Крім того, жінка опікується закладами інституційного догляду та виховання дітей у районі проведення АТО.

Окрім суто волонтерської діяльності, Вікторії доводилося надавати першу медичну допомогу та евакуйовувати постраждалих, перебуваючи у першій медроті Пирогова. У лютому 2015 року жінка отримала перше поранення, потрапивши під мінометний обстріл в Кримському, на Луганщині, коли через лобове скло у бронежилет влучив уламок, що потрощив ребра та плечовий суглоб. Трохи згодом, влітку, у тому ж Кримському Вікторія отримала важку контузію. Вона допомагає українським бійцям від самого початку війни, іiі не зупиняють ні отримані поранення, ні контузії. У Вікторії поєднується все - сильний характер і хвилинна слабкість, добре серце і непримиренність, любов і байдужність, так і ні [11].

Вікторія Мірошниченко нагороджена орденом “Народний Герой України”, орденом “За заслуги” від Президента України, а також “Знаком пошани" Міністерства оборони України за значний внесок в обороноздатність держави та підтримку Збройних Сил України [12]. 
Діана Макарова - засновниця ФОНДу оперативної національної допомоги, до якого входить група активістів із надання допомоги військовослужбовцям Збройних Сил України та Національної гвардії України, пораненим, внутрішньо переміщеним особам, сім'ям військовослужбовців [13].

Д. Макарова зі своїми близькими та друзями 3 перших днів Євромайдану надавала допомогу сотням Самооборони Майдану. Її блог Diana_ledi в “живому журналі” 3 січня 2014 р. перетворився на штаб допомоги та блогерський фонд, кошти до якого перераховували читачі блогу. Навесні бійці самооборони записалися у Національну гвардію і після підготовки на полігоні у Нових Петрівцях сформований із них батальйон відправився на Схід, до міста Слов'янськ. Фонд почав допомагати батальйону, поступово підтримка поширилася й на інші підрозділи.

Указом Президента України Діана Макарова нагороджена Орденом княгині Ольги III ступеня за громадянську мужність, вагомий особистий внесок у розвиток волонтерського руху, зміцнення обороноздатності і безпеки Української держави. 3 нагоди Міжнародного дня волонтера Міністр оборони України нагородив Діану Макарову іменною зброєю за визначні заслуги у забезпеченні обороноздатності України і зміцненні національної безпеки.

Олена Масоріна - засновниця Фонду допомоги армії "Волонтерська сотня “Україна-Світ”, народний депутат України 8-го скликання [14]. Олена Масоріна була учасником Свромайдану та допомагала пораненим активістам; iз початком АТО стала допомагати амуніцією, обладнанням та медикаментами військовим на Сході України. За волонтерську діяльність Указом Президента України Олена Масоріна була нагороджена Орденом княгині Ольги III ступеня.

Аліна Михайлова потрапила у волонтерський рух ще під час Революції Гідності. У 2014 році була головою дніпровського відділу волонтерської організації “Армія SOS” [15], організовуючи збирання та довезення 
гуманітарної допомоги в район проведення АТО. Після кількох років активного волонтерства Аліна намагалася “зав'язати” $з$ війною, але не вийшло. Попри волонтерську діяльність, займалася аеророзвідкою, пройшла вишкіл і увійшла до складу батальйону “Госпітальєрів”, заснованого у липні 2014 року після боїв за Карлівку та Піски. За час існування батальйону було врятовано щонайменше 2500 бійців, проте “Госпітальєри” й досі залишаються волонтерською структурою. Сьогодні Аліна періодично буває на передовій, підтримуючи новачків. 3 нагоди Дня Незалежності України Указом Президента України Аліну Михайлову нагороджено медаллю України “Захиснику Вітчизни”.

Отже, жінки-волонтери зробили вагомий внесок у загальний волонтерський рух. Нарівні з чоловіками вони долали усі труднощі та спромоглися забезпечити українських захисників найнеобхіднішим у скрутний для держави час. Безперестанна праця цих жінок врятувала на фронті не одне життя. На думку авторки, завдяки жінкам-волонтерам та героїзму i самопожертві українських воїнів Україна зберегла свій суверенітет, зупинила російську агресію та відновила боєздатну армію 3 високим моральним духом.

\section{Список використаних джерел і літератури}

1. Роменчанка стала героиней книги “Жінка волонтер-жінка герой”: [Електрон. ресурс]. - Режим доступу: http://www.romny.online/romenchankastala-geroyineyu-knygy-zhinka-zhinka-volonter-zhinka-geroy (дата звернення 17.09.2018).

2. Ежегодный рейтинг 100 самых влиятельных женщин Украины: [Електрон. ресурс]. - Режим доступу: https://focus.ua/ukraine/319776/ (дата звернення 26.09.2018).

3. Біла книга - 2014. Збройні Сили України. - К. : МОУ, 2015. - 85 с.

4. Біла книга - 2017. Збройні Сили України. - К. : МОУ, 2018. - 152 с. 
5. Ричкова T. Низький уклін Вам, українські волонтери! // Народна Армія. - 2018. - Вип. 35 (5567).

6. Ричкова Т. Б.: [Електрон. ресурс]. - Режим доступу : https://uk.wikipedia.org/wiki/ (дата звернення 18.09.2018).

7. Большое сердце: Самые известные волонтеры Украины: [Електрон. pecypc]. - Режим доступу: https://112/.ua/statji/bolshoe-serdce-samye-izvestnyevolontery-ukraine-276672.html (дата звернення 18.09.2018).

8. Волонтер Раїса Шматко: для мене на війні: [Електрон. ресурс]. Режим доступу : https://dt.ua/personalities/volonter-rayisa-shmatko-dlya-menena-viyni-naystrashnishe-bachiti-tam-ditey-html (дата звернення 25.09.2018).

9. Пачера М. Буденний героїзм волонтерки Шматко // Вечірній Київ. 2018. - Вип. 33 (19318).

10. Обличчя війни: Вікторія Мірошниченко - позивний "Рижик": [Електрон. pесурс]. - Режим доступу : https://uavarta.org/2017/10/03 (дата звернення 27.09.2018).

11. Воронщов П. Так і Ні волонтера Вікторії Мірошниченко // Голос України. - 2018. - Вип. 134 (6889).

12. Президент нагородив полтавську волонтерку: [Електрон. ресурс]. Режим доступу : https://tribuna.pl.ua/news/prezident-nagorodiv-poltavskuvolonterku/ (дата звернення 27.09.2018).

13. Фонд Діани Макарової: [Електрон. ресурс]. - Режим доступу : https://uk.wikipedia.org/wiki/ (дата звернення 28.09.2018).

14. Масоріна Олена Сергіївна: [Електрон. ресурс]. - Режим доступу : https://uk.wikipedia.org/wiki/ (дата звернення 02.10.2018).

15. Аліна Михайлова. Думаєте, люди, які на війні, ніколи не переведуться? Так не буде!: [Електрон. ресурс]. - Режим доступу : https://hromadskeradio.org/programs/kyiv-donbas/dumayete-lyudy-yaki-na-viyninikoly-ne-perevedutsya-tak-ne-bude-alina-myhaylova (дата звернення 02.10.2018). 
Novikova V.H., Senior Researcher of Research Division of Research Center of Military History of Ivan Chernyakhovskyi National Defense University of Ukraine (Kyiv)

\section{THE ROLE AND PLACE OF WOMEN IN THE VOLUNTEER MOVEMENT DURING THE PERIOD OF ANTI-TERRORIST OPERATION (2014-2018)}

The article analyzes the participation of women in the volunteer movement, which arose during the Revolution of Dignity and unfolded during an armed conflict in the East of Ukraine. In an extremely difficult period this movement has united the society, created an effective structure of public organizations, groups of people, ready to take on the solution of the most pressing and painful problems of the state.

Keywords: volunteer movement, volunteer women, anti-terrorist operation. 